\title{
Postcolonial Elements in Early English Poetry
}

\author{
Mohamed Kamel Abdel-Daem
}

Shaqra University, Saudi Arabia

Reconsidering the old and early medieval English poetry, one may notice that a great deal of verse reflects the atmosphere of conflict prevailing at the time. The poets used poetry to commend living or dead people: heroes, knights, holy figures and nobles. The praised champions often defended their homeland against invaders in order to preserve their inherited national identity. This gives AngloSaxon( to A.D.1066) and Anglo-Norman( 1066-1340) poetry an importance in the realm of postcolonial studies. The warlike life experienced by both the AngloSaxons and the Anglo-Normans can be considered a major factor of the poets' adoption of heroic themes and tones. The first people in England were foreigners Celts) who came from abroad and inhabited England along with a long-settled race, the Britons. These races had different, ethnic qualities that were fostered by their worshipping a multitude of local deities. In 55 B.C, they were invaded by the Romans, and afterwards, they were attacked by the barbarians - the Angles, the Saxons and the Jutes, then by the Teutons, and later on by the Danes (Morgan 159). Being always exposed to invasions, these heterogeneous ancient races looked highly upon the knights who can defy any coming danger. No wonder then that the creatures they imaginatively admired were dragons and monsters hiding in caves and lakes. They were enchanted by tempestuous seas and fierce battles. But when St. Augustine brought Christianity to England in A.D. 597, those harsh people ceased to be in conflict against each other. The new religion embodied a new philosophy, and a race that not long before had been eerily savage was soon burning with religious enthusiasm, expounding their new doctrine and its figures (Morgan 60-119). During the Anglo-Norman period, the struggle was directed against the French colonizers; when William the Conqueror invaded England in 1066, he faced severe resistance at the hands of the English native champions; many changes were observed in English society, language(a mixture of French and Old English) and consequently poetry. A feudal system, which was profitable only to the powerful French lords, was imposed on the country(Morgan 120-191). 
The poets or troubadours played an important role in forming and preserving a unified national identity of the ancient English who came from different environments. Interestingly, the formation and preservation of national identity in ethnic, and colonized, communities is the primary concern of postcolonial literature which is often seen as a category that:

covers a very wide range of writings from countries that were once colonies or dependencies of the European powers. There has been much debate about the term: should predominantly white ex-colonies like Ireland, Canada and Australia be included? Why are the United Sates exempted both from the accepted list of former colonies and from the category of colonizing powers? In practice, the term is applied most often to writings from Africa, the Indian sub-continent, the Caribbean, and other regions whose histories during the $20^{\text {th }}$ century are marked by colonialism, anti-colonial movements, and the subsequent transitions to post-Independence society ... postcolonial theory, which developed in the 1980s and 1990s under the influence of E. Said's Orientalism, considers vexed cultural-political questions of national and ethnic identity, 'otherness', race, imperialism, and language, during and after the colonial periods. It draws upon post-structuralist theories such as those of deconstruction in order to unravel the complex relations between imperial 'center' and colonial 'periphery', often in ways that have been criticized for being excessively abstruse(Baldick 265).

Postcolonial literature describes a broad diversity of experiences created in the existence of heterogeneous societies which have many different ethnic groups. This applies to Anglo-Saxon and Anglo-Norman poetry; it expresses the interests of various tribes: heroic, supernatural, religious, elegiac and chivalric (romantic). Postcolonial theory is often defined as the discussion of " migration, slavery, suppression, resistance, representation, difference, race, gender, place and responses to influential master discourses of imperial Europe ... and the fundamental experiences of speaking and writing by which all these come into being"(Ashcroft 2). Several races have contributed to the creation of old and earlymiddle English: Scandinavian, Celtic, Roman, Danish and Norman. This was the outcome of colonialism, making a language spoken by both the colonizer and colonized. The invaders bring their own customs and diction. The colonizers' words interact with the original ones, and this produces new terms that reflect the postcolonial reality (New 303-4). The diverse themes of earlier English poetry 
reflect a kind of cultural (and linguistic) resistance and conflict between the different ethnics; " decolonization is a process, not arrival ... it has been the project of post-colonial writing to interrogate [colonizers'] discourses and discursive strategies from a privileged position within (and between) two worlds" (Tiffin 95).

Studying earlier English poetry leads us to considering the concept of ethnicity. There has been a long controversy whether ethnicity is to be regarded as primordial or as an instrumental phenomenon. Primordialism describes social identity as unchangeable, and cultures as canonical texts (Eriksen 55, Schoenbrun 47). Social groups exist as social objects a priori (Amselle 21). Ethnicity is then understood as a cultural thing; "those aspects of social relationships and processes in which cultural difference is communicated" (Eriksen 127). It is also considered as the " articulation of internal and external networks of exchange" (Bayart 216). Moreover, there are two main mechanisms by which identity is coined and transferred: the first is represented in the feelings of sameness and unity, the second is distinctiveness(Jacobson-Widding 13). Also, resistance to colonial hegemony gives the different social entities a more defined identity (Brandstrom 4):

The strength of nationalism as political phenomenon is its ability to draw on sentiments - language, religion, family, culture - that appear to be natural and autochthonous. Their cultural expression required the emergence of a set of hew and hardly autochthonous circumstances ... Its force depends on the capturing of primordial sentiments, even though the drawing together of language, religion, or culture with polity is generally a modern phenomenon (Kemper 244).

The introduction of a new religion (Christianity) and the translation of Biblical texts has helped in constituting a unified English identity and discourse( Schoenburn 55, Davidson 71). Heterogenity thus forms an integral part of cultural making. The colonizers' culture and language often mix with that of the colonized. This illustrates Chinua Achebe's assumption that colonized peoples " lived at the crossroads of cultures ... the crossroad does have a certain dangerous potency; dangerous because a man might perish there wrestling with multipleheaded spirits ... he might be lucky and return to his people with the boon of prophetic vision"( Achebe 190-1). 
Postcolonialism could not just be thought of as an articulation of imperial process; rather, it articulates a multiplicity of 'centres' or emergent identities, thus:

The first stage of a process of de-scribing Empire is to analyse where and how our view of things is inflected (or infected) by colonialism and its constituent elements of racism, over-categorization, and deferral to centre. The processes of history and European historicizing ... should not seduce us into believing that de-scribing empire is a project simply of historical recuperation ... The postcolonial is especially and pressingly concerned with the power that resides in discourse and textuality, its resistance, then, quite appropriately takes place in and from the domain of textuality in (among other things) motivated acts of reading (Tiffin,1994 9)

Such imperial reality often causes the emergence of hybridity, a term that comes from biology and is used in postcolonial studies to refer to mixture of races and tongues (Young,1995). It denotes the effects of colonization upon identity and culture. In The Location of Culture, Homi K. Bhabha analyses the liminality of hybridity as a model of colonial fright. He sees that colonial hybridity has created ambivalence in the colonial masters and as such altered the authority of power (115). Mikhail Bakhtin's concept of polyphony is used by many analysts of hybrid discourse in folklore and anthropology(Hutnyc 106-36). Zuckermann used hybridity in linguistics; he sees that the formation of a new language "demonstrates that the reality of linguistic genesis is far more complex than a simple family tree system allows. 'Revived' languages are unlikely to have a single parent"(63).

Depending upon such definitions, the proposed dissertation will display and scrutinize the postcolonial marks employed in Anglo-Saxon and Anglo-Norman poetry in order to keep a unified national identity; that is to say - praise of heroism, religious devotion, romance's chivalric pride, and the expression of elegiac feeling. The poets tried to attract people to different beloved items in the English island: their love for legendary heroes who could challenge supernatural powers, their love for religious figures, their love for adventures done to gain women's hearts, and their love for dead honourable men.

The multi-raced people were partly attracted to their homeland by the heroic attitude of the old English heathen poets. Those old English poets believed in superstition and heroism " with a sense of endurance, of fate, and of unfailing 
courage revealing a spirit that is never completely recaptured in any later period"(Evans 19). In Beowulf, the monsters are depicted as God's foes and the thane as a divine champion. The Battle of Maldon portrays the defeat of Byrhtonth's men at the hands of the Viking invaders; it finds in defeat an opportunity to celebrate the heroic ideal, contrasting the resolution of Byrhtonth's warriors to avenge his death with the cowardice of others who horrifyingly quitted the battlefield. The Battle of Brunanburh portrays the occasion of King Athelston's triumph over an army of Norsemen and Scots:

Then Aethelstan, king, Thane of eorls,

Ring- bestower to men, and his brother also, The atheling Edmund, lifelong honour

........Broke the shieldwall,

Split shields with swords.

The poets also sang of the rituals dedicated to attracting the peoples to their idols, the magic or supernatural powers and hymns devoted for royal celebrations. A lot of verses were addressed to Erce, the mother of earth, to furnish the fields with her grace and to preserve their fertility. Poems such as Beowulf, The Seafarer, Deor, The Wanderer and The Ruin show that the poets were interested in the adventurous life of the sea. The poems reflect the struggle between man and monsters, between sailors and the stormy weather (Ward vol.I, ch. III,4-13);

In Beowulf, the hero battles three antagonists and beats two, but in the final battle, he is fatally wounded, dies and is buried in a tumulus in Geatland:

High oér his head they hoist the standard, A gold-wove banner; let billows take him, Gave him to ocean. Grave were their spirits,

No hero 'neath heaven, - who harbored that freight!

The heroic virtues in the poem are evidently the Anglo-Saxon's as " the majority view appears to be that people ... in Beowulf are based on real people in the $6^{\text {th }}$ century Scandinavia, and that the poem is contextually based on folktale type" (Anderson 115). Although Hrothgar and Beowulf are portrayed as:

morally upright pagans, they fully espouse and frequently affirm values of Germanic heroic poetry ... depicting warrior society, the most important of human relationships was that which existed between the warrior and his 
lord, a relationship based less on subordination of one man's will to another's than on mutual trust and respect(Abrams 30).

Old English heroic poetry was both created and performed by the Scop, or poet, who usually recited verses aloud before a group of upper-class listeners. Accompanied by the harp, he used to add to the entertainment of his patron's guests by telling about stories of bygone deeds, battles of earliest times and the extraordinary skill of his lord's forefathers. This heroic poetry used alliteration and stress in the place of rhyme in order to echo powerfully in the recipients' hearts. Another salient feature of this pagan poetry was the use of many phantasmal metaphors or kennings for common subjects: the poets referred to the sea as the " whale's way", "gannet's bath", "swan's riding" and so on (Burgess 17-8). Peter S. Baker sees that the alliterative lines and the rapid rhyme enabled the poets to talk about descriptions of battles and adventures:

Anglo-Saxons wrote what we call alliterative poetry after its most salient feature, the system of alliteration that binds its verses together and is largely responsible for its distinctive sound. Similar metrical systems are found in old Icelandic, old Saxon and old High German: all of these cultures inherited a common Germanic meter, which they adopted as their languages and cultures changed. English poets continued to write alliterative poetry as late as the fifteenth century... the poetry also employed a strict rhythmic scheme ... the line consists of two verses( also called half-lines) divided by a syntactical boundary called a caesura. Each verse must conform to rhythmic patterns or types. Verses of all types have in common that they always contain two stressed syllables, called lifts, and two or more groups of unstressed syllables, called drops. The first verse in a line is generally called the on-verse and the second verse is called the off-verse. Only the alliteration of lifts is significant. In each poetic line one or two lifts in the on-verse must alliterate with the first in the off-verse. The second lift in the off-verse normally does not alliterate with any of the three other stressed syllables in the line ... there is a strong tendency in old English poetry to group weakly stressed words that are not proclitic at the beginning of a clause or immediately after the first lift in a clause ... a half-stress may sometimes be treated as part of the drop and sometimes as the lift (Baker 44-5). 
After the advent of Christianity in England, people ceased to be loyal to the polytheistic idols or gods. The Anglo-Saxon poets wrote religious poems in which they praised God's creations, the Christ and the saints, showing the merits of converting to Christianity. This also joined the people to a united aim. According to Bede, Caedmon, the first Christian English poet, became poet after an angel visited him and ordered him to sing the "Song of Creation" ( Bede IV, ch 24, 10), Caedmon's Hymn:

Now we must praise the Guardian of the kingdom of heaven,

The might of the Creator and the thought of His mind,

The work of the Father of men, as He, the Eternal Lord,

Formed the beginning of every wonder

This poem presents accounts of creation based on translations of the Old and New Testaments that are included in the Bible which is:

a composite book, consisting of two main sections - the Old Testament and the New. The Old Testament, originally written mainly in Hebrew, is a collection of poems, plays, proverbs, prophecy, philosophy, history, theology - a massive anthology of writings of the ancient Jewish people. The New Testament, originally written in Greek, contains the Gospels and the story of the spreading of Christianity by its first propagandists ... The Old Testament Apocrypha consists of historical and philosophical writings. The New Testament Apocrypha gives ... further details of the lives of the Apostles, the birth and resurrection of Christ, etc.(Burgess 39).

Bede reports that Caedmon "could never compose any foolish or trivial poem, but only those which were concerned with devotion" (Bede IV, ch 24,16). In Christ and Satan, Caedmon speaks about the horrors of the day of judgment, terrors of hell and pleasures of the heavenly paradise. The first part of the poem deals with the fall of the angels; the second is about the resurrection of Christ and the harrowing hell, entailed with a short account of Christ's ascension and return to the world; the third part tells about how Satan tried to tempt the Christ. In Genesis, Caedmon makes a poetical paraphrase of the first of the orthodox books in the Old Testament, proceeding to the story of Abraham's sacrifice of his son. The poem opens with the praise of the Creator, then continues to relate the protest and fall of the angels, and then the creation of the earth and the tale of the Satan who determined to tempt man in revenge for having fallen from his grand status. In Exodus, the poet tells the story of the Israelites' passage through the Red Sea and 
the destruction of Pharaoh's army. In Daniel, we learn about the life of St. Daniel and his endeavours to convey moral lessons(Ward vol.I, ch.IV,3-6).

Cynewulf, another significant Anglo-Saxon poet, produced a great deal of verse, eulogizing religious figures and virtues. In Guthlac, Cynewulf relates the life of the Mercian saint, Guthlac. The wonderful light that shines over Guthlac's cottage before his death distinctly recalls the charming lights of the sky. When the saint enters into the heavenly paradise, the whole English land shakes with delight. Then the poet moves into the saint's last great fight with the powers of darkness and death. The Dream of the Rood tackles the story of crucifixion, showing the cross as a provider of self-assurance and help. Like his earlier predecessors, the poet arrests the attention of his audience by: "Lo, Listenth, lordings". The technique must have been a common one in days when , at festive meetings, the harp was plucked at (Watts 201). In Crist, Cynewulf deals with the advent of Christ on earth, his ascension, then his second return to judge the world. Elene tells the story of finding the cross by St Helena, the mother of the Roman emperor Constantine:

Then straightway in the presence of the nobles Elene accomplished all .........and unto her own Son she sent the glorious present

And the queen began to teach the Throng

Of her dear subjects that they

Should steadfastly hold to the love of the Lord

The conversion of the emperor is carried out when he sees a vision of the cross in the sky. Thus, the cross was "transmuted from being a symbol of ignominy to a symbol of glory", and it began to be extolled (Brown 23).In Andreas, we see how St Andrew converts the Mermedonians by performing miracles(Ward vol.I,ch.IV,7-11).

In the Dream of the Rood, Cynewulf praises the Christ as a Saviour of all human beings:

Then the young hero (who was God Almighty)

Got ready, resolute and strong in heart.

... the warrior embraced [the cross] 
He climbed onto the lofty gallows-tree

Bold in the sight of many watching men,

When He intended to redeem mankind.

And then I saw the Lord of all mankind

Hasten with eager zeal that he

Might mount upon me.

Jeannette C. Brock states that the poet:

depicts Christ as a purposeful courageous warrior who boldly confronts and defeats sin...instead of simply using the word " Christ", the poet calls Jesus "the young hero" and "mankind's brave king". These images create a vivid image of Christ which echoes the description of Beowulf who is praised as a " king", "the hero", and a "valiant warrior". . . later, the poet suggests that Christ actually initiates the battle to redeem mankind. The poet emphasizes the voluntariness of Christ's undertaking of crucifixion(Brock 1-19).

There were also Anglo-Norman poems that are concerned with expressing religious faithfulness. Love Ron is a religious lyric that tells about the happiness of marriage with the Heavenly Bridegroom. Handling Sin, a series of metrical homilies, deals with the Ten Commandments, the Seven Deadly Sins, the Seven Sacraments and the Twelve Spiritual Graces. The Prick of Conscience and Moral Poem urge people to do good works and holy things. The Course of the World advises people to read about religious stories - Creation of the World and the Judgment Day. Winter Wakens all My Care treats the transience of life's joy. Athelston,, Guy of Warwick, and Dispute between the Body and the Soul also tackle religious issues. Richard Rolle's "A Song of Mercy", "The Nature of Love"," A Song of Love-Longing to Jesus" and "Thy Joy be in the Love of Jesus" were written in praise of God, Christ and the Virgin. William Langland's poems( e.g. The Vision of Pier the Plowman) laudably approve of the true religion exemplified in the life of Christ ( Ward vol I, ch XI-XV):

In a somer seson, when soft was the sunne, I shope me in shroudes, as I a shepherd were, In habite as an hermite, unholy of werkes, Went wide in this worlde, wondwers to here. 
The poets' attempt to form a unified, national English identity is also reflected in the early-middle English chivalric romance which is:

the principal kind of romance found in medieval Europe from the $12^{\text {th }}$ century onwards, describing( usually in verse) the adventures of legendary knights, and celebrating an idealized code of civilized behaviour that combines loyalty, honour, and courtly love. The emphasis on [sensual] love and courtly manners distinguishes it from the chanson de geste and other kinds of epic, in which masculine military heroism predominates

romance is a fictional story in verse or prose that relates improbable adventures of idealized characters in some remote or enchanted setting; or, more generally, a tendency in fiction opposite to that of realism . . . it usually refers to the tales of King Arthur's knights(Baldick 54, 291)

The troubadours or minstrels were responsible for the production of verse romances in England under the Normans. They wrote narrative poems or medieval French epics which are products of a feudal age; being so, they are affected by the conventions of chivalry. The Celtic legends connected with the adventures of King Arthur and his knights shaped the main part of the themes about Britain ( e.g., King Horn and Havelock the Dane). The first pieces of Anglo-Norman verse writings( that appeared around 1200) mostly pivoted on religious matters: homilies, litanies, preaching, stories about saints. The earliest poems were written with the aim to guide people to the merits of Christian creed. Then, English secular poets began to display their contributions, most of them imitating the French writings that aimed at entertaining the feudal lords. There is a lot of fancy in the stories told about Arthur and other noblemen. However, the Normans regarded these tales as historical facts. Layamon's Brut, for instance, depicted Arthur as a chivalric hero, paving the way for many middle English poets to take their main inspiration from such Arthurian legends (Ker 104-6). Afterwards, there were the ensuing metrical romances( e.g., Sir Gawain and the Green Knight):

Oér a mound on the morrow he merrily rides

Into a forest full deep and wondrously wild:

High hills on each side and holt woods beneath

With huge hoary oaks, a hundred together 
These metrical romances are English narrative poems that have been mostly copied from French work. They were much influenced by the writings of the Norman poets, and were concerned with knightly adventures and the aid of maidens in distress. Then followed a number of courtly love romances( e.g., Romance of the Rose); they can be considered as depictions of love sentiment(Hibbard 49-82).

As one of the Arthurian romances, King Horn is based on chivalric adventures to present two themes: loyalty for love or family, and the rightful acquisition of land or status:

You think I am a beggar,
But I am a fisherman,
Come far into the east
.....................
My net lies here
By this beautiful shore

Horn, the hero, is gushed over for being involved in a number of battles with the Saracens - who come from the sea. He defeats them to prove his worthiness of being a knight and consequently win his love, Rimenild, to revenge his father's murder, and to regain his lands( Benson 73-80).

The quintessence of romance sprang from Scandinavia[ source of Beowulf] in the form of mythical tales. In addition, we are often enthralled by legendary elements, such as gods, dwarves, fairies, dragons, giants and magic swords. The heroes usually set off on dangerous quests where they challenge the forces of evil, witches, living skeletons, and rescue their fair damsels. The $13^{\text {th }}$ and $14^{\text {th }}$ - century new courtly love romance was related to the Matter of Britain. Though still full of adventure, it devotes an unprecedented amount of time to dealing with the psychological aspects of love. On the other hand, the stories of the pre-Chaucerian romances focused not upon affection and sentiment, but upon adventure and gallantry, except some love lyrics such as Alison (Hibbard 278-90)

By a gracious chance I have caught it. I know it has

Been sent from heaven. From all other

Women I have taken away my love:

It has alighted on Alison 
The elegiac elements in both Anglo-Saxon and Anglo-Norman poems represent an important way of preserving national identity; praising dead figures or bygone virtues could teach people how dear their land is:

Since the pagan philosophy of the afterlife is dim, at best and so much of Old and Middle English period celebrates the heroic deaths of warriors in battle, the elegy form is of great importance in adding humanistic value to otherwise senseless savagery (Lambdin 174)

The old English elegies bewail the loss of secular good, prosperity, or human comradeship. The Wanderer is told by a man, who lost patron and family, and whose journeys make him realize that only in heaven man can find stability. The Seafarer is similar, but the speaker's spiritual longing is overtly sympolized by the poem's journey motif. Several other poems have comparable subjects, and three elegies - The Husband's Message, The Wife's Lament, and Wulf and Edwacer describe what seems to be a familiar case: the separation of husband and wife by husband's exile. Deor bridges the gap between elegy and the heroic poem, for in it the poet regrets the loss of his position at court by referring to mythological Germanic tales. Beowulf itself depicts the battles of a leader against two monsters, containing some of the best elegiac verse; by setting magnificent stories beside historical background in which triumph is always temporary and strife is always renewed, the poet gives the whole an elegiac cast (Encyclopedia Britannica).

The elegiac mood in Deor can be obviously noticed in the poem's sorrowful life; the speaker is fatalistic, though at the same time is courageous and determined:

I wish to say this about myself:

That for a time I was the Heodening's poet,

Dear to my lord - my name was 'Deor'.

For many years I had a profitable position

The lament atmosphere is found in the refrain to Deor, where the poet is anguished because he has been estranged from his lord; he reminds himself of the bygone predicaments: "That grief passed away: so may this sorrow pass". Resigned melancholy is a characteristic of many Anglo-Saxon poems. Even when a poem is at its most vigorous - dealing with war, storm, sea, the drinking-hall, the creation of the world - we always seem to be aware of a certain undercurrent of sadness. 
Perhaps this is a reflection of the English climate or, due to the fact that English, compared with French, is much harsher in sound (Burgess 20).

Juliana is a religious elegy that weeps over the torture the Christians experienced under the rule of the Roman emperor, Maximian, and over the tragic martyrdom of St. Juliana:

From town to town fared mighty officers,

As he had hidden them

They wrought hostility,

Setting up graven images;

They slew the saints, and destroyed

Those who were versed in Scripture

Juliana vehemently resists being married to the pagan Eleusis so as not to violate her relationship with God. Eleusis ghastly punishes Juliana by getting her beaten with rods, thrown into prison, and finally beheaded. The poem's style is based on a military or battlefield language; this helps create the metaphor that the martyr's spirit was a sort of impenetrable fortress, impervious to the attacks of polytheism( Frederick 70-3).

The Anglo-Normans also used elegy. The Pearl displays an elegy through an impressive lament of a little girl. Besides The Pearl, there are other early medieval elegies: John Skelton's The Boke of Phyllyp Sparowe, Stephen Hawes's The Pastime of Pleasure, William Dunbar's "The Lament for the Makaris". The Pearl displays a long lament in a very ornamental language on the death of a child and a vision of the heaven to which she has gone:

Before at spot my hande I spinned

For careful colde at to me cast;

I playned my perle at er wat spenned

I felle upon at flowery flat

Being sad at the loss of his daughter, the speaker is transported - in one of his dreams - to an other-worldly garden. There, he sees a young maid whom he identifies as his Pearl. She tells him that he lost nothing and that his Pearl is merely a rose which has naturally withered. Then she instructs him on several religious 
aspects: sin, repentance, grace and salvation, and asks him to go to the heavenly city of God. When he awakes, he resolves to fulfill the will of God. Both the elegiac and the allegorical( or symbolic) aspects of the poem make it "the most highly wrought and intricately constructed poem in Middle English"(Bishop 27), based upon a frequent, but not consistent, use of alliteration.

The present study tries to examine the postcolonial elements found in the poetic works of the Anglo-Saxon era ( to A.D. 1066) and the Anglo-Norman period (1066-1340). It applies the features of postcolonialism on the works of the old and the early-medieval English poets (before Chaucer) in order to see how the poets tried to save a unified national identity. Generally speaking, the study is to be nestled on an intensive look at pre-Christian English poems( such as Beowulf, Finnsburg, The Battle of Maldon, The Battle of Brunanburh, Widsith, Waldere, "Wulf and Edwacer", "The Wife's Lament", "The Husband's Message", "The Ruin", "Deor", "The Seafarer", "The Wanderer", and Charms); old English religious poems (such as Caedmon's Hymn, Daniel, Exodus, Genesis, Crist and Satan, Judith; Cynewulf's Dream of the Rood, Andreas, Elene, Juliana, Guthlac, Physiologus, The Phoenix, The Fates of the Apostles, Crist, Genesis B); old English poetical homilies such as Address of the Lost/Saved Soul to the Body, Gifts of Men, Fates of Men;Bede's Death Song); early medieval English romances such as( Sir Gawain and the Green Knight, King Horn, Havelok the Dane, Athelston, The Tale of Beryn, Robert Mannyng's Meditations, Layamon's Brut, William Langland's The Vision of Piers The Plowman); love poems such as (Alison, A Song on the Passion, Canute Song, and Tristram and Iseult).

The method of approaching this topic will be mainly theoritical and ontological. Through a heuristic reading of Anglo-Saxon and Anglo-Norman poetic texts, one may be able to apply postcolonial theory to ways used by poets to coin a unified English identity ( e.g., heroism, religious devotion, chivalry and elegy). So far, the textual analysis will be chiefly based on: Beowulf, Caedmon's Hymn and Genesis, Cynewulf's The Dream of the Rood and Elene, King Horn and Havelok the Dane, Deor and The Pearl; yet references to other poems will be necessary.

Contribution: This study manifestly assumes that nineteenth and twentiethcentury, imperial England had once been a colonized nation that produced postcolonial culture and literature. This proposed dissertation will also prove that postcolonialism is not restricted just to modern times; postcolonial literature often 
emerged where conflicts occurred. The study also will hint at the impact of postcolonial elements( race, religion, language) on English poetry.

\section{References and notes:}

Cook, A.S. et al. Translations from the Old English. Hamden, CT: Archon Books, 1970. French, W.H. \& C.B.Hale. Middle English Metrical Romances. New York: Prentice Hall, 1930

--------------------. Translation of King Horn. English Romance Reader. USA: UWA, 1995

Heany, Seamus, trans. Beowulf - A New Verse Translation. Ed. Daniel Donoghue. New York: Norton, 2001.

Holt, Lucius Hudson, trans. The Elene of Cynewulf. New York: Henry Holt \&Co., 1904 Moorman, Charles, ed. The Works of the Gawain-Poet. N Y: Jackson, 1977

Murch, Herbert Spencer. Translation of Cynewulf's Juliana. The Journal of English and Germanic Philology. Vol.5,No3(1905):303-19

William, Vantuono,ed. The Pearl Poems: An Omnibus Edition. New York: Garland., 1984

Abrams, M.H.\& Greenblatt Stephen. "Beowulf". The Norton Anthology of English Literature: The Middle Ages( vol 1). New York: W.W. Norton, 2000

Achebe, Chinua. Hopes and Impediments. London: Doubleday, 1988

Amselle, Jean-Loup. Anthropology and Historicity. Ed. V.Y. Mudimbe \& B. Jewsiewick: Middletown: Weslyan Univ., 1993

Anderson, Carl Edlund. Formation and Resolution of Ideological Contrast in the Early History of Scandinavia. USA:CUP,1999

Andrea, Bernadette, "Early Modern Women, 'Race' and (Post)Colonial Writing". Ariel.27.3(1996):127-49

Ashcroft, Bill., Gareth Griffiths \& Helen Tiffin( eds). The Post-Colonial Studies Reader. London: Routledge, 1995

Baker, Peter S. Introduction to Old English. Oxford: Blackwall,2003

Baldick, Chris.The Oxford Dictionary of Literary Terms, 2nd ed., N.Y: OUP,2008

Bayart, Jean-Francois. The State in Africa: The Politics of the Belly. London: Longman, 1993

Bede, the Venerable. Ecclesiastical History of the English People. Rev. ed.London: Penguin, 1990.

Benson, Larry. "Thematic Structure in King Horn." Malory's Morte Darthur. London: Methuen, 1976

Bhabha, K. Homi. The Location of Culture. London: Routledge, 1994

Bishop, Ian. "Pearl in its Setting". A Critical Study of the Structure and Meaning of the Middle English Poem. Oxford:OUP, 1968

Brass, Paul R. Ethnicity and Nationalism: Theory and Comparison. New Delhi: Sage Publications, 1991

Brock, C.Jeannette. "The Dream of the Rood \& the Image of Christ in Early Middle Ages" The Anglo-saxon Warrior Culture.Scribd Documents.August2009.p.119.Scribd.<http//www.scribd.com/brocks/html>

Brown, C.F. "Irish-Latin Influence in Cynewulfian Texts". Englische Studien, XI.( 1909): 1-29

Burgess, Antony. English Literature. England: Longman, 1974. 
Clutterbuck, Charlotte, Encounters with God in Medieval and Early Modern English Poetry. USA:Ashgate, 2005

Comaroff, John L. \& Paul C. Stern. New Perspectives on Nationalism and War.

Luxembourg: Gordon \& Breach, 1995

Davidson, Basil. Modern Africa: A Social and Political History. 3rd ed. London: Longman, 1994

Eriksen, Thomas Hylland. The Cultural Contexts of Ethnic Differences". Man (N.S). vol

26. no 1( 1991):127-44

Press, 1993

Evans, Ifor. A Short History of English Literature. 4th ed. England: Penguin Books, 1976.

Frederick, Jill. "Warring with Words: Cynewulf's Juliana." Readings in Medieval Texts. Ed.

Dvid Johnson. New York: Oxford,2005

Greenfield, S.B.\& D.G.Calder. A New Critical History of Old English Literature. London: Faber, 1986

Hibbard, Laura A. Medieval Romance in England. New York: Burt Franklin,1963

Huppe, Bernard Felix. Doctrine and Poetry:Augustine's Influence on Old English Poetry. Albany: State Univ. of New York, 1959.

Hutnyc, John. "Adorno at Womad: South Asian Crossovers and the Limits of Hybriditytalk". Debating Cultural Hybridity. Ed. Tariq Modood \& Pnina Werbner. London: Zed Books, 1997

Jacobson-Widding, Anita. Identity: Personal and Socio-Cultural. A Symbosium. Uppsala: Acta Univ, 1983

Kapchan, Deborah A. \& P.T. Strong, eds. "Theorizing the Hybridity". Journal of American Folklore. Vol 1. no 445( 1999): 29-53

Kemper, Steven. The Presence of the Past: Chronicles, Politics and Culture in Sinhala Life. Ithaca: Cornell UP, 1991

Kennedy, Charles W. Old English Elegies. Princeton: Prin.U P, 1936.

Ker, W.P. Medieval English Literature. London: O.U.P, 1969

Lambdin, R.T. \&L.C.Lambdin. eds. Encyclopedia of Medieval Literature USA: Greenwood Publishing Group, 2000

Lapidge, Micael et.al. Anglo-Saxon England. New York: CUP,1991

Legge, M.D. Anglo-Norman Literature and its Background. New York: O.UP, 1963

Levine, Robert." Aspects of Grotesque Realism in Sir Gawain and the Green Knight." The Chaucer Review, vol.17,No1(summer1982):65-75

Matonis, A.T.E. "Tradition of Panegyric in Welsh Poetry:The Heroic and the Chivalric". Speculum. Vol 53, No 4(Oct.1978)667-87

Morgan, Kenneth O. The Oxford History of Britain. Oxford: OUP,2001

Morris, Richard,ed. "Early English Alliterative Poems", EETS. 1(1965)

New, W.H. "New Language, New World". in Aschroft, 1978

Quayson, Ato \& David T. Goldberg. Relocating Postcolonialism. N Y: Wiley Blackwell, 2002

Schlauch, M. English Medieval Literature and its Social Foundations. London: Heffer, 1956

Schoenbrun, David L. " A Past Whose Time Has Come: Historical Context and History in Eastern Africa's Great Lakes". History Making in Africa. Eds. V.Y Mudimbe \& B. Jewsiewicki. Middletown: Wesleyan Univ,1993

Tiffin, Helen. "Post-Colonial Literature and Counter-discourse". in Ashcroft,1987 
Ward\& Trent et al. eds. The Cambridge History of English and American Literature. An Encyclopedia in 18 volumes.New York: G.P Putnan's Sons, 1907-21;New York:Bartleby2000(wwwbartlebycom/Cambridge)[25 Nov.2010]

Watts, Ann Chalmers. The Lyre and the Harp. New Haven: Yale Univ. Press, 1969.

Weston, J.L. From Ritual to Romance. London: CUP, 1920

Young, Robert. Colonial Desire: Hybridity in Theory, Culture and Race. London: Routledge, 1995

Zuckermann, Ghil'ad. "Hybridity versus Revivability: Multiple Caucasian Forms and Patterns". Journal of Language Contact. Varia 2(2009): 40-67

"English Literature". Encyclopedia Britannica. Encyclopedia Britannica Online. 2011.web. 22Jan 2011.<EB./checked/topic/188217/English Literature>

\title{
Summary
}

\section{Postcolonial Elements in Early English Poetry}

\author{
Mohamed Kamel Abdel-Daem \\ (Shaqra University, Saudi Arabia)
}

In this article, the writer highlights certain elements in Anglo-Saxon and Anglo-Norman verse, that can unsurprisingly be a precursor of postcolonial writing. These marks are: heroic spirit, religious devotion, chivalric pride and elegiac vein. All these topics were nothing but aids to the early English poets' attempt to coin a unified English identity. This study manifestly assumes that nineteenth and twentieth century, imperial England had once been a colonized nation that produced postcolonial culture and literature. This article proposes that postcolonialism is not restricted just to modern times; postcolonial literature often emerged where conflicts occurred. The study also hints at the impact of postcolonial elements( race, religion, language) on English poetry.

Key Words: postcolonialism, ethnicity, hybridity, national identity 